\title{
Monitoring of Aflatoxin B1 in Dry Aged Meats using a modified HPLC-FLD method
}

\author{
HATICE AHU KAHRAMAN ${ }^{1, a,(*)}$, HIDAYET TUTUN ${ }^{2, b}$ \\ ${ }^{1}$ Burdur Mehmet Akif Ersoy University, Faculty of Veterinary Medicine, Department of Food \\ Hygiene and Technology, 15030, Burdur, Turkey \\ ${ }^{2}$ Burdur Mehmet Akif Ersoy University, Faculty of Veterinary Medicine, Department of \\ Pharmacology and Toxicology, 15030, Burdur, Turkey \\ ORCIDs: ${ }^{\mathrm{a}}$ 0000-0001-6600-239X, ${ }^{\mathrm{b}}$ 0000-0001-9512-8637
}

\begin{abstract}
The presence of aflatoxins residues in meat and meat products occurs through ingestion of feeds contaminated with Aflatoxin B1 (AFB1) or during the processing of the meat products. Little research has been conducted concerning the detection of AFB1 on meat. The aim of this study was to modify the method for AFB1 determination by high performance liquid chromatography with fluorescence detection in dry aged meats. The aged meat samples used for determination of AFB1 were obtained from a commercial dry aged meat plants and produced for 28 days in a meat plant chiller. All meat samples were analyzed according to the modified method. The samples were cleaned to remove impurities by using a immunoaffinity column. Photochemical reactor was used for the recording and evaluation of the chromatograms. The analytical performance parameters showed that the method was specific for AFB1 detection in the meat samples. Recovery rate, reproducibility (RSDr\%) and repeatability (RSDR\%) were found to be $85.889 \%$, $3.822 \%$ and $6.601 \%$, respectively. Limit of detection and limit of quantification were $0.15 \mathrm{ng} / \mathrm{mL}$ and $0.501 \mathrm{ng} / \mathrm{mL}$, respectively. AFB1 was not detected in the meat samples. Our results indicated that the method modified for monitoring AFB1 level in the meats was simple, time-saving and reliable.
\end{abstract}

Keywords Aflatoxin B1, beef, dry-aging, HPLC-FLD.

To cite this article: KAHRAMAN HA, TUTUN H. Monitoring of Aflatoxin B1 in Dry Aged Meats using a modified HPLC-FLD method. Rom Biotechnol Lett. 2021; 26(4): 2885-2891. DOI: $10.25083 / \mathrm{rbl} / 26.4 / 2885-2891$ 


\section{Introduction}

Mycotoxins are a diverse group of secondary metabolites produced by three main filamentous fungal genera: Aspergillus, Penicillium, and Fusarium. Mycotoxins occur more frequently in areas with a hot and humid climate, favourable for the growth of molds. They are entering the food-chain through contaminated food or feed (FREIRE, 2018; IQBAL, 2014; UNUSAN, 2019; KEYVAN, 2018; TURKOGLU, 2019). Mycotoxicoses are the diseases caused by the mycotoxins, particularly aflatoxins (AFs) and ochratoxin A (OTA), which exert toxic effects on animals and humans that result from ingestion of these mycotoxins (ADEYEYE, 2016; KUÇUKÇAKAN, 2016). AFs are considered the most important mycotoxin in foods and feeds due to causing acute liver damage is being significantly carcinogenic, mutagenic and teratogenic in livestock, domestic animals and human (SAMUEL, 2009; SARMA, 2017; AWUCHI, 2020; ONYEKE, 2020).

Consumption of animal feeds contaminated with aflatoxins produced by the fungi at the time of their harvesting, processing, storage, transport and distribution may result in appearance of the aflatoxins in animal body tissues such as liver, kidney and meat (ADEYEYE, 2020; AL-RUWAILI, 2018). Also, aflatoxins can occur in foods of animal origin at any stage of their production, processing, transport, and storage (CINAR, 2019; OYERO, 2020). The ingestion of aflatoxins from contaminated meat obtained from animals feeding with contaminated feeds and during processing of these meats causes serious health problems in humans (ADEGBEYE, 2020). Human exposure to aflatoxins are a big concern in developing countries and considered as an unavoidable contaminant in foods and feeds $(\mathrm{OH}, 2019)$.

Meats and meat products comprise an important source of valuable proteins for human diet and have substantial effects on people health. Meat and meat-based products such as sausages, burger, luncheon, basterma and dry aged meat can be source of aflatoxins (MARKOV, 2013; REFAI, 2003). The fact that ambient conditions are suitable for the growth of aflatoxin-producing fungi during meat processing and that aflatoxins are thermostable chemical compounds increases the risk of meat contamination with aflatoxin. Dry aging is a method where carcasses or primal cuts are aged for 28 to 55 day under controlled environmental conditions. During this process, meat is aged in a controlled aerobic environment (KAHRAMAN, 2018). Throughout this process, the water activity $\left(a_{\mathrm{w}}\right)$ of the meat surface decreases, which leads to the reduce of certain food pathogens but simultaneously provides a better environment for the growth of yeast and molds (AWUCHI, 2020; ALGINO, 2007; TITTOR, 2011). Thus, there may be a potential safety risks related to mold growth that may occur during dry aging period.
Aflatoxins may find in meats as tissue residues obtained from contaminated feeds or occur as a result of toxinogenesis during meat processing. Therefore, aflatoxin residue analysis in food and feed is important for the protection of public health. High performance liquid chromatography (HPLC) is a method used for analysis of aflatoxins in feeds and foods together with fluorescence detector (FLD) (CUI, 2017). It is important to have reliable, accurate, sensitive, and quick analytical method for determination of aflatoxin residue level in different kinds of food. In this study, it was aimed to modify the method for identification and quantification of aflatoxin B1 (AFB1) by HPLC-FLD in dry aged meats.

\section{Material and Methods}

\section{Reagents and Standard Preparation}

HPLC standard preparation and sample spiking were modified from VICAM (AflatesT® HPLC Procedure, Vicam) and AOAC Official methods 2003.02 (AOAC, 2006). As aflatoxins are toxic substances, they were always manipulated in solution and nitrile gloves were used for all procedures performed in this study. Standard dilutions of $0,0.4,0.8,1.2,2.4,3.6$ and $5.4 \mathrm{ng} / \mathrm{mL}$ were prepared for AFB1 from aflatoxins mix standard (1000 ng/mL AFB1, 300 ng/mL AFB2, 1000 ng/mL AFG1 and $300 \mathrm{ng} / \mathrm{mL}$ AFG2; purity 98\%) purchased from Supelco (Bellefonte, PA, USA) in methanol: water (40:60, v:v) and stored at $-20^{\circ} \mathrm{C}$. Each standard solution $(100 \mu \mathrm{L})$ was injected into the HPLC system to calculate the standard curve. The samples were cleaned to remove impurities by using the immunoaffinity column from VICAM (Cat. No. 12022). Methanol, water for HPLC and sodium chloride $(\mathrm{NaCI})$ were purchased from Sigma (St. Louis, MO, USA). All reagents used for the HPLC were of analytical grade. $24 \mathrm{~cm}$ fluted filter paper (Cat. No. 31240 ) and $11 \mathrm{~cm}$ microfibre filter papers (Cat. No. 31955) were purchased from Vicam. The HPLC analysis was carried out on $\mathrm{C} 18,5 \mu \mathrm{m}, 250 \times 4.6 \mathrm{~mm}$ column from ACE (Cat. No: ACE-121-2546 ACT, Aberdeen, Scotland).

\section{Sampling}

The aged meat samples $(n=30)$ used for determination of AFB1 were obtained from a commercial dry aged meat plants in Antalya and produced in meat chiller in Burdur.

Dry aged meat production: The meat samples (Longissimus lumborum muscle) were obtained from a local slaughterhouse in Burdur province of Turkey and shipped to the laboratory in Burdur Mehmet Akif Ersoy University under cold chain. The dry aging treatment of the meat samples $(n=20)$ was carried out at $+1^{\circ} \mathrm{C}, 87 \%$ relative humidity and $0.2-0.5$ meter/sec air flow for 28 days in a commercial meat chiller according to our previous study (KAHRAMAN, 2019). The meat trim samples were taken before and after aging. Also, the trim samples taken 
before aging were used as blank for validation of the method. All samples were kept at $-80^{\circ} \mathrm{C}$ until analysis.

Dry aged meat samples obtained from meat plants: The meats (Longissimus lumborum muscle, approx. $300 \mathrm{~g}$ ) aged for 28 days $(n=10)$ were collected aseptically from dry aged meat plants and transferred to the laboratory under cold chain for the period of September-October 2019 in Antalya province of Turkey. Each sample was taken and packaged in a polivinil bag, then stored at $-80^{\circ} \mathrm{C}$ until the analysis. All meat samples were analyzed according to the method modified in this study.

\section{Extraction of Aflatoxin B1}

Extraction prodecure used in the current study was modified from VICAM (Aflatest ${ }^{\circledR}$ HPLC Procedure, Vicam). Each meat sample (50 gram) was thawed and homogenated in a sterile blender jar with $200 \mu \mathrm{g} \mathrm{NaCl}$ and $4 \mathrm{~mL}$ of a methanol:water $(80: 20, \mathrm{v}: \mathrm{v})$ per gram of meat sample for $2 \mathrm{~min}$ with a tissue homogenizer (WiseTis Homogenizer, HG-15D, Daihan Scientific). After the homogenates were clarified by filtration through fluted filter paper (VICAM, 31240), $10 \mathrm{~mL}$ of each filtrate was diluted with $40 \mathrm{~mL}$ of purified water. The diluted extract was filtered through glass microfibre filter (VICAM, 31955). $10 \mathrm{~mL}$ filtered diluted extract ( $10 \mathrm{~mL}=0.5 \mathrm{~g}$ sample equivalent $)$ was applied to an immun-affinity column (AflaTest, Vicam, Miford, MA, USA) at a flow rate of 1-2 drops/sec. The columns were washed with $10 \mathrm{~mL}$ of purified water at a flow rate of about 2 drops per sec. This step was repeated once more until air comes through the column. The columns were dried by applying a low vacuum for 5 to 10 seconds using the injector. $1.0 \mathrm{~mL}$ HPLC grade methanol was added at a rate of $1 \mathrm{drop} / \mathrm{sec}$ into glass syringe barrel. The eluate was collected $(1.0 \mathrm{~mL})$ in a glass cuvette (VICAM part \# 34000) and $1.0 \mathrm{~mL}$ of purified water was added to the cuvette. $100 \mu \mathrm{L}$ of the reconstituted sample were injected into the HPLC system, and monitored using fluorescent detector at 362 and $440 \mathrm{~nm}$ for excitation and emission, respectively.

\section{HPLC-FLD Analysis}

The chromatography was performed by Agilent 1260 Infinity HPLC (Agilent Technologies, Santa Clara, CA, USA) equipped with G1311C pump, G1316A column oven, and G1321B fluorescence detector (Model FL 2475, FLD) at wavelength 362 and $440 \mathrm{~nm}$ for excitation and emission, respectively. The column used was 250 x $4.6 \mathrm{~mm}$ C18, $5 \mu \mathrm{m}$ from ACE (Aberdeen, Scotland) and was kept at $30^{\circ} \mathrm{C}$. The flow rate of the mobile phase was maintained at $1.0 \mathrm{~mL} / \mathrm{min}$ and the injection volume was $100 \mu \mathrm{L}$. The mobile phase was consisted of water: methanol: acetonitrile (57:29:14, v/v/v). Under these conditions, retention time was about $14 \mathrm{~min}$ for AFB1. Agilent ChemStation software (Version B.04.03, Agilent Technologies) for LC 3D system was used for the recording and evaluation of the chromatograms. Total run time was 16 min. The HPLC analytical conditions are shown in Table 1 .

Table 1. Analytical conditions for HPLC

\begin{tabular}{ll}
\hline Parameter & \multicolumn{1}{c}{ Operation Conditions } \\
\hline Instrument & Agilent 1260 Infinity HPLC system (Agilent Technologies, USA) \\
Column & $\mathrm{C} 18$ column; $4.6 \mathrm{~mm}$ (internal diameter) x 250 mm (lenght), $\mu \mathrm{m}$ \\
& (Aberdeen, Scotland) \\
Mobile phase & $\mathrm{A}=$ water; $\mathrm{B}=$ methanol; C = acetonitrile; A/B/C = 57:29:14 \\
Column temperature & $29-30^{\circ} \mathrm{C}$ \\
Flow rate & $1.0 \mathrm{~mL} / \mathrm{min}$ \\
Pressure & $<300 \mathrm{bar}$ \\
Detector & $\mathrm{G} 1321 \mathrm{~B}$ fluorescence detector (Model FL 2475) \\
Detection wavelength & Wavelength 362 and 440 nm for excitation and emission, respectively \\
Retention time for AFB1 & 14.012 min \\
\hline
\end{tabular}

\section{Validation of the HPLC-FLD Method}

A mixed AF standard was prepared by spiking AF free samples of the meat with four AFs (AFB1, AFB2, AFG1 and AFG2) to concentrations of 5 and $10 \mathrm{ng} / \mathrm{mL}$. The spiked samples were kept overnight at room temperature $\left(24^{\circ} \mathrm{C}\right)$ and then extracted and analysed for the AFB1. The concentrations of AF were counted using a calibration curves prepared from the standard AFB 1 in the range of $0.0-5.4 \mathrm{ng} / \mathrm{mL}$. The analytical method was validated for AFB1 according to the following method performance characteristics: Limits of detection (LOD), limits of quantification (LOQ), recovery, linearity, precision and accuracy.

\section{LOD and LOQ}

The aflatoxin-free meat sample was spiked at low concentration (AFB1: $0.5 \mathrm{ng} / \mathrm{mL}$ ) and 10 independent studies were performed by two different staff. LOD and LOQ were calculated using standard deviation of all results. 


\section{Linearity}

Linear range was found in linearity assessment experiments. Linearity was determined by triplicate injections $(100 \mu \mathrm{L})$ of six different concentrations of standards obtained by dilution in methanol. The calibration curve was constructed by plotting the concentration of AFB1 injected to the device versus the respective peak areas and the linear regression equation was calculated by the instrument. The correlation coefficient $\left(\mathrm{R}^{2}\right)$ was calculated by the linear regression.

\section{Precision}

For the repeatability assay, the meats were spiked with AFB1 standard at 3 different concentrations (0.5 ng/mL, $2 \mathrm{ng} / \mathrm{mL}$ and $5 \mathrm{ng} / \mathrm{mL})$. On the same day, two analysts performed 10 independent trials for $0.5 \mathrm{ng} / \mathrm{mL}$ concentration and 6 independent trials for the other 2 concentrations in the same laboratory. Grubbs' test was used to determine a single outlier in raw data. Precision of the relative standard deviation (RSDr) (repeatability RSD) for repeatability for all concentration of AFB1 in the meat was calculated according to the value obtained from Horwitz equation. Also, ANOVA test was used to determine whether there was any difference between the individuals. For the reproducibility assay (within laboratory), the uncontaminated meat samples were spiked with $0.5 \mathrm{ng} / \mathrm{mL}, 2 \mathrm{ng} / \mathrm{mL}$ and $5 \mathrm{ng} / \mathrm{mL}$ of standard AFB1. Analysis of all samples were performed by two analysts on six different days using independently prepared reagents and sample preparations. The relative standard deviation of reproducibility (RSDR) was calculated by using Horwitz equation.

\section{Trueness (Bias, Recovery)}

Systematic error (Bias) is calculated for Trueness. Systematic error indicates the ability of a measurement method to give the true result. Recovery values (\%) for the meat were calculated by dividing the experimental AFB1 concentration obtained by the nominal AFB1 level. Known concentrations of AFB1 standard $(0.5 \mathrm{ng} / \mathrm{mL}$, $2 \mathrm{ng} / \mathrm{mL}$ and $5 \mathrm{ng} / \mathrm{mL}$ ) were added to blank meat samples for recovery experiments. The experiments were performed by two analysts. The concentration of AFB 1 was calculated using calibration curves constructed using standard AFB1 solutions $(0.0-5 \mathrm{ng} / \mathrm{mL})$. The recovery was calculated according to the following formula:

$$
\begin{aligned}
& \% \mathrm{R}=\mathrm{C} 1 \times 100 / \mathrm{C} 2 \\
& \mathrm{R}=\mathrm{Recovery} \\
& \mathrm{C} 1=\text { value read in the spiked sample } \\
& \mathrm{C} 2=\text { Spike concentration }
\end{aligned}
$$

\section{Results}

The standard curves were found to be linear with correlation coefficient of 0.998 . The peak of the AFB1 was observed at a retention time of $14.012 \mathrm{~min}$ (Figure 1). Averages of the LOD and LOQ, recovery rate, repeatibility and reproducibility values are shown in Table 2. The methods showed good recoveries (85.88\%) with relative standart deviation value (4.219) (Table 2, Figure 2). The LOD and LOQ values were $0.15 \mathrm{ng} / \mathrm{mL}$ and $0.501 \mathrm{ng} / \mathrm{mL}$ for AFB1, respectively. AFB 1 was not detected in the dry aged meats which were both produced and collected from the commercial meat plants.

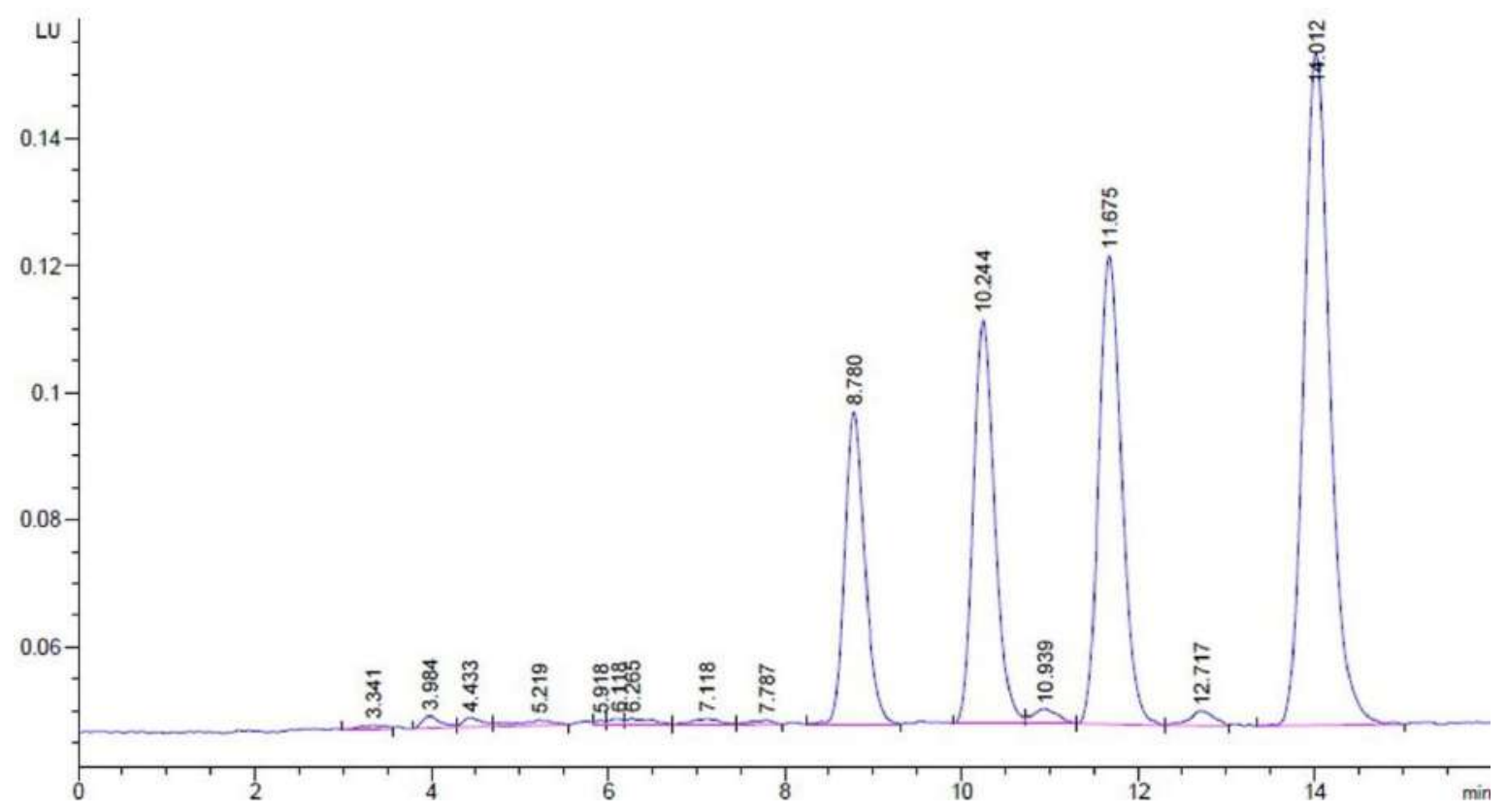

Figure 1. Chromatogram of the standard solutions of AFB1 at concentration of $1.2 \mathrm{ng} / \mathrm{mL}$. AFB1, AFB2, AFG1 and AFG2 of RT are 14.012, 11.675, 10.244 and 8.780, respectively 
Table 2. Validation parameters for the HPLC method

\begin{tabular}{ll}
\hline Parameters & B 1 value \\
\hline LOD $(\mathrm{ng} / \mathrm{mL})$ & 0.15 \\
LOQ $(\mathrm{ng} / \mathrm{mL})$ & 0.501 \\
Linear range $(\mathrm{ng} / 100 \mu \mathrm{L}) \mathrm{R}>0.99$ & $0.04-0.54$ \\
Repeatibility (\%RSDR) & 6.601 \\
Reproducibility (\%RSD) & 3.822 \\
Recovery (\%) & 85.889 \\
\hline
\end{tabular}

$\mathrm{LOD}=$ Limit of detection; $\mathrm{LOQ}=$ Limit of quantification

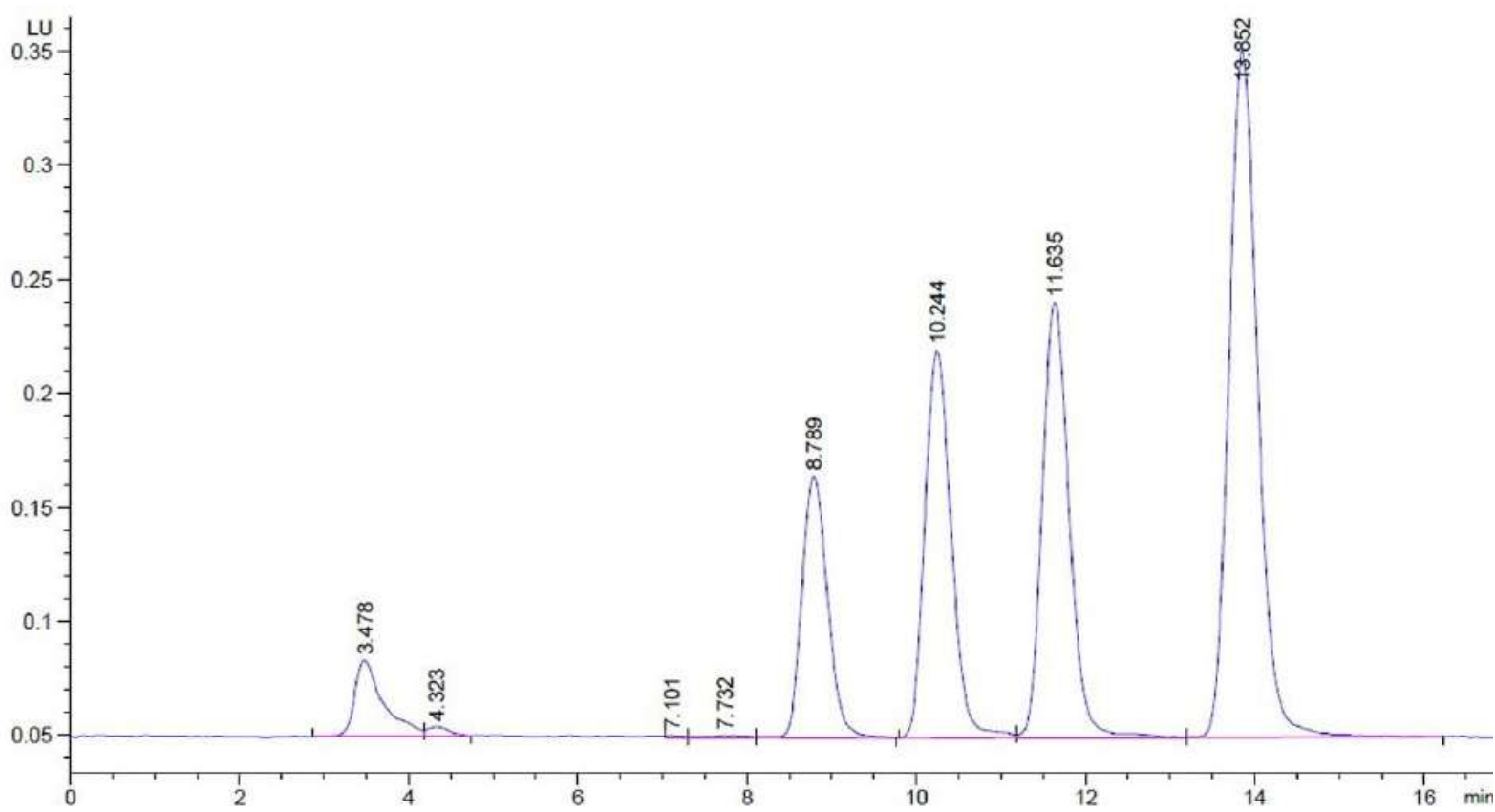

Figure 2. Chromatogram obtained from samples spiked with $5 \mathrm{ng} / \mathrm{mL}$ AFB1

\section{Discussion}

The residue of Aflatoxin B1 which is a potent toxic for animals and human in different types of meat has been reported in previous studies (OYERO, 2020; PLEADIN, 2015). There is a high need for a method capable of highly sensitive and selective detection of AFB1 in cattle meat. In this study, a fast, robust and reliable HPLC method was developed by modifying the method for the determination of AFB 1 residues in cattle meats. For the quantitative analysis of AFB1 standard, HPLC method was optimized and validated. Validation of the method was achieved by recovery, repeatability, repoductibility, LOD, LOQ and linearity.

Extraction is first and important step in detection of aflatoxins in food and feed samples. Aflatoxins are generally soluble in polar protic solvents like benzene methanol, acetone chloroform, acetonitrile and extracted by blending with these solvents or water, either single or as mixtures (BERTUZZI, 2012; KURONEN, 1993). In the current study, a methanol:water mixture was used.
Immunoaffinity colum which is used for immunoaffinity cleanup step for mycotoxins provides quick and highly sensitivity and recovery for total determination of mycotoxins in food and feed in the extraction procedures (CUI, 2017; CHOOCHUAY, 2018; PEARSON, 1999). The developed method provided high sensitive and accurate detection of AFB1 residue in cattle beef by using immunoaffinity column as an alternative to expensive and time-consuming methods.

Mobile phase composition is important due to its effects on peak responses and retention of analytes. Mobile phase generally composes of solvents like toluene, dichloromethane, chloroform, ethyl acetate, formic acid, methanol acetonitrile, water for analysis of aflatoxins in several matrices (CUI, 2017; KURONEN, 1993; CORCUERA, 2011; HERZALLAH, 2009; HUSSAIN, 2016). Among the mixtures made using these solvents, the most preferred is the mixture of methanol, water and acetonitrile. The mobile phase used in this study was a mixture of these solvents (acetonitrile:methanol:water, 14:29:57, $\mathrm{v}: \mathrm{v}: \mathrm{v})$. 
In previous studies on optimization of HPLC analytical methods for AFB1 in meats, recovery rates were found to be $95.10 \%$ (HERZALLAH, 2009) for AFB1 from beef samples and $84.88 \%$ (CUI, 2017) for AFB1 from muscle tissues of broiler chickens. In the present study, the recovery rate $(85.889 \%)$ with low relative standard deviation demonstrated that the modified method was accurate over the tested concentration range.

Contamination of meat and meat products with mycotoxins occurs via feeding the animals with contaminated feeds or during the processing and their distribution. The acceptability and overall liking of meat products can be influenced by the microbiological quality of the meat. There are many techniques used to increase acceptability and quality of meat products. Dry-aging, a method of aging in which meat is placed under controlled environmental conditions, improves both meat tenderness and flavour. However, dry aging provides a suitable environment favorable for the fungal growth. The growth of aflatoxin-producing fungi in the process of dry aging can cause serious health problems (REFAI, 2003). Little research has been conducted on aflatoxin production and contamination in meats. In the previous studies on detection of AFB 1 in meats, it has been founded that AFB1 levels in meats ranged from 0.001 to $8.32 \mu \mathrm{g} / \mathrm{kg}$ (IQBAL, 2014; OYERO, 2020; HERZALLAH, 2009; NABIL, 2014). In dried meats, OYERO and OYEFOLU (2020) have identified Aspergillus niger, A. tamari, A. fumigatus, A. terreus, A. flavus, A. citrinum, A. sydowii, Penicillium oxalicum, $P$. chrysogenum, Rhizopus nigrificans and $R$. oligosporus. In dry-aged meats, $\mathrm{OH}$ et al. (2019) have identified P. oxalicum, P. echinulatum, Mucor circinelloides, and P. anomala and TAPP et al. (2015) found AFB1 at concentration of $0.1875 \mathrm{ppb}$ with ELISA. In this study, no AFB1 has been found in the dry-aged samples.

\section{Conclusion}

The results obtained in this study revealed that the modified method for monitoring AFB1 level in dry aged meat was simple, time-saving, accurate and reliable. No AFB1 was found in the meat samples analyzed by this modified method.

\section{Financial Support}

This research received no grant from any funding agency/sector.

\section{Conflict of Interest}

The authors declared that there is no conflict of interest.

\section{Author Contributions}

HAK and HT designed the experiment. HAK provided samples, HT carried out HPLC analysis. All authors wrote the manuscript.

\section{References}

1. ADEGBEYE MJ, REDDY PRK, CHILAKA CA, BALOGUN OB, ELGHANDOUR MM, RIVASCACERES RR, SALEM AZ. Mycotoxin toxicity and residue in animal products: Prevalence, consumer exposure and reduction strategies - A review. Toxicon. 2020; 177, 96-108. doi: 10.1016/j.toxicon.2020.01.007

2. ADEYEYE SAO. Aflatoxigenic fungi and mycotoxins in food: a review. Crit Rev Food Sci Nutr. 2020, 60 (5), 709-721.doi: 10.1080/ 10408398.2018. 1548429

3. ADEYEYE SAO. Fungal mycotoxins in foods: A review. Cogent Food Agric. 2016; 2: 1213127. doi: 10.1080/23311932.2016.1213127

4. ALGINO RG, INGHAM SC, ZHU J. Survey of antimicrobial effects of beef carcass intervention treatments in very small state-inspected slaughter plants. J Food Sci. 2007; 72 (5): 173-179. doi: 10.1111/j.1750-3841.2007. 00386.x

5. AL-RUWAILI M, ALKHALAILEH NI, HERZALLAH SM, RAWASHDEH A, FATAFTAH A, HOLLEY R. Reduction of aflatoxin b1 residues in meat and organs of broiler chickens by lactic acid bacteria. Pak Vet J. 2018; 38 (3), 325-328. doi: 10.29261/pakvetj/2018.064.

6. ASSOCIATION OF OFFICIAL ANALYTICAL CHEMISTS (AOAC). EDITOR: HORWITZ W. Aflatoxin B1 in cattle feed. In book: Official methods of Analysis of the AOAC International, $18^{\text {th }} \mathrm{ed}$, AOAC International, Maryland, USA, 2006, pp. 38284.

7. AWUCHI CG, AMAGWULA IO, PRIYA P, KUMAR R, YEZDANI U, KHAN MG. Aflatoxins in foods and feeds: A Review on health implications, detection and control. Bull Env Pharmacol Life Sci. 2020; 9, 149-155.

8. BERTUZZI T, RASTELLI S, MULAZZI A, PIETRI A. Evaluation and improvement of extraction methods for the analysis of aflatoxins B1, B2, G1 and G2 from naturally contaminated maize. Food Anal Methods. 2012; 5 (3): 512-519. doi: 10.1007/s12161-011-9274-5

9. CHOOCHUAY S, PHAKAM J, JALA P, MANEEBOON T, TANSAKUL N. Determination of aflatoxin B1 in feedstuffs without clean-up step by highperformance liquid chromatography. Int J Anal Che. 2018; 2018: 1-8. doi:10.1155/2018/4650764

10. CINAR A, ONBAŞI E. EDITOR: SABUNCUOGLU S. Mycotoxins: The Hidden Danger in Foods In book: Mycotoxins and Food Safety, IntechOpen, London, UK, 2019. doi: 10.5772/intechopen.89001

11. CORCUERA LA, IBÁÑEZ-VEA M, VETTORAZZI A. Validation of a UHPLC-FLD analytical method for the simultaneous quantification of aflatoxin B1 and ochratoxin A in rat plasma, liver and kidney. J Chromatogr B. 2011; 879: 2733-2740. doi: 10.1016/j.jchromb.2011.07.039 
12. CUI X, MUHAMMAD I, LI R, JIN H, GUO Z YANG Y, HAMID S, LI J, CHENG P, ZHANG X. Development of a UPLC-FLD method for detection of aflatoxin B1 and M1 in animal tissue to study the effect of curcumin on mycotoxin clearance rates. Front Pharmacol. 2017; 8: 650. doi: 10.3389/ fphar.2017.00650

13. FREIRE L, SANT'ANA AS. Modified mycotoxins: An updated review on their formation, detection, occurrence, and toxic effects. Food Chem Toxicol. 2018; 111, 189-205. doi: 10.1016/j.fct.2017.11.021

14. HERZALLAH SM. Determination of aflatoxins in eggs, milk, meat and meat products using HPLC fluorescent and UV detectors. Food Chem. 2009; 114 (3): 1141-1146. doi: 10.1016/j.foodchem.2008.10.077

15. HUSSAIN Z, REHMAN HU, MANZOOR S, TAHIR S, MUKHTAR M. Determination of liver and muscle aflatoxin $\mathrm{B} 1$ residues and select serum chemistry variables during chronic aflatoxicosis in broiler chickens. Vet Clin Pathol. 2016; 45 (2): 330334. doi: $10.1111 / \mathrm{vcp} .12336$

16. IQBAL SZ, NISAR S, ASI MR. Jinap S, Natural incidence of aflatoxins, ochratoxin $\mathrm{A}$ and zearalenone in chicken meat and eggs. Food Control. 2014; 43: 98-103. doi: 10.1016/j.foodcont.2014.02.046

17. KAHRAMAN HA, GURBUZ U. Aging applications on beef meat. MANAS. 2018; 6 (1): 7-13.

18. KAHRAMAN HA, GURBUZ U. Effects of three aging methods on the Longissimus lumborum muscle from Holstein-Friesian steers. Med Weter. 2019; 75 (3): 179-184. doi: 10.21521/mw.6182

19. KEYVAN E, YURDAKUL O, KOCASARI F, TUTUN H, DEMIRTAŞ A, KAHRAMAN HA, SEN E. Detection of ochratoxin A in bulk tank milk. Kocatepe Vet J. 2018; 11: 255-259. doi: $10.30607 / \mathrm{kvj} .424808$

20. KUÇUKÇAKAN B, STOJANOVSKA-DIMZOSKA B, HAJRULAI-MUSIU Z, DIMITRIESKA-STOJKOVIC E, UZUNOV R, DAVCHEVA K. Determination of ochratoxin-A in cattle liver by HPLC-FD method. Kafkas Univ Vet Fak Der. 2016; 22 (1): 1-5. doi: $/ 0.9775 / \mathrm{kvfd} .2015 .13236$

21. KURONEN P. EDITOR: Betina V. Techniques of Liquid Column Chromatography. In book: Journal of Chromatography Library, Elsevier, US, 1993.

22. MARKOV K, PLEADIN J, BEVARDI M, VAHCIC N, SOKOLIV-MIHALAK D, FRECE J. Natural occurrence of aflatoxin B1, ochratoxin A and citrinin in Croatian fermented meat products. Food Control. 2013; 34 (2): 312-317. doi: 10.1016/j.foodcont.2013. 05.002

23. NABIL HASSAN M, ABD EL AZIZ HASSAN A, HASANINE TARTOR Y, FAROUK ALI S. Aflatoxin producing moulds and aflatoxin residues in meat and meat products in Egypt. Zagazig Vet J. 2014; 42 (3): 43-55. doi: 10.21608/ZVJZ.2014.60042
24. OH H, LEE HJ, LEE J, JO C, YOON Y. Identification of microorganisms associated with the quality improvement of dry-aged beef through microbiome analysis and DNA sequencing, and evaluation of their effects on beef quality. J Food Sci. 2019; 84 (10): 2944-2954. doi: 10.1111/1750-3841.14813

25. ONYEKE CC. Review of mycotoxins in foods in Nigeria. Food Control. 2020; 118, 107376. doi: 10.1016/j.foodcont.2020.107376

26. OYERO OG, OYEFOLU AB. Natural occurrence of aflatoxin residues in fresh and sun-dried meat in Nigeria. Pan Afr Med J. 2020; 7: 14. doi: 10.4314/ pamj. v7i1.69124

27. PEARSON SM, CANDLISH AAG, AIDOO KE, SMITH JE. Determination of aflatoxin levels in pistachio and cashew nuts using immunoaffinity column clean-up with HPLC and fluorescence detection. Biotechnol Tech. 1999; 13(2):97-99.

28. PLEADIN J, STAVER MM, VAHČIĆ N, KOVACEVIC D, MILONE S, SAFTIC L, SCORTICHINI G. Survey of aflatoxin B1 and ochratoxin A occurrence in traditional meat products coming from Croatian households and markets. Food Control. 2015; 52: 71-77. doi: 10.1016/j.foodcont.2014.12.027

29. REFAI MK, NIAZI ZM, AZIZ NH, KHAFAGA NEM. Incidence of aflatoxin B1 in the Egyptain cured meat basterma and control by $\gamma$-irradiation. Food/ Nahrung. 2003; 47 (6): 377-382. doi: 10.1002/food. 200390085

30. SAMUEL N, EZRI Y, FARAH R, IGOR V, HUSSEIN A, RUBINSHTEIN O, ASSY N. Acute aflatoxicosis resulting in fulminant hepatic failure and rhabdomyolysis. Gastroent Res. 2009; 2 (1): 48-50. doi: 10.4021/gr2009.01.1254

31. SARMA UP, BHETARIA PJ, DEVI P, VARMA A, Aflatoxins: implications on health. Indian J Clin Biochem. 2017; 32 (2), 124-133. doi: 10.1007/s12291017-0649-2

32. TAPP III W, HANLON K, NIGHTINGALE K, SAN FRANCISCO M, MILLER $M$, BRASHEARS $M$. Molecular evaluation of mold growth and aflatoxin presence on dry aged beef. International Association for Food Protection Congress, July 25-28, Portland, Oregon, 2015.

33. TITTOR AW, TITTOR MG, BRASHEARS MM, BROOKS JC, GARMYN AJ, MILLER MF. Effects of simulated dry and wet chilling and aging of beef fat and lean tissues on the reduction of Escherichia coli 0157:H7 and Salmonella. J Food Protect. 2011; 74 (2): 289-253). doi: 10.4315/0362-028X.JFP-10-295

34. TURKOGLU C, KEYVAN E. Determination of aflatoxin M1 and ochratoxin A in raw, pasteurized and UHT milk in Turkey. Acta Sci Vet. 2019; 47: 1626. doi: 10.22456/1679-9216.89667

35. UNUSAN N. Systematic review of mycotoxins in food and feeds in Turkey. Food Control. 2019; 97, 1-14. doi: 10.1016/j.foodcont.2018.10.015 